\title{
Od zabawy lalkami do zabawy słowami - tomiki wierszy dla dzieci Pawła Beręsewicza
}

From playing with dolls to playing with words Paweł Beręsewicz's poetry books for children

\begin{abstract}
The paper includes the analyses of three books of poems by Paweł Beręsewicz: Lalki Dorotki [Dorotka's dolls] (2004), Czy pisarzom burczy w brzuchu? [Do writers' stomachs grumble?] (2009) oraz Złota jedenastka... [The golden eleven...] (2018). The author studies language, composition, the voice and characters creation, as well as the main idea of the three books, also paying attention to illustrations. She reconstructs the status of a speaker and a recipient, and their relationship (i.e. an adult-child relationship). It is also an attempt to place Beręsewicz's books of poems in the context of his stories and novels.
\end{abstract}

Keywords: Paweł Beręsewicz, poetry books for children, doll, play, child-adult relationship, metafiction, illustrations, sports in literature

Paweł Beręsewicz jest pisarzem znanym, lubianym przez czytelników i nagradzanym (m.in. dwukrotnie Nagrodą Literacką im. Kornela Makuszyńskiego w 2008 i 2011 roku). Do końca 2019 roku opublikował ponad trzydzieści książek, w większości opowiadań i powieści dla dzieci oraz trzy tomiki poetyckie. Jego debiutem książkowym był właśnie niepozorny tomik z wierszami. W 2004 roku krakowskie wydawnictwo Skrzat wydało Lalki Dorotki z przesłodzonymi ilustracjami Jolanty Adamus-Ludwikowskiej. Drugie wydanie z 2011 roku ukazało się z równie nieudaną, infantylną szatą graficzną autorstwa Marty Ostrowskiej, w niefortunny sposób - moim zdaniem - kierującą lekturą. To nie są bowiem grzeczne wierszyki dla grzecznych dziewczynek, jak sugerowałaby wzięta w różowe ramki okładka i podobnie różowe, błyszczące kolorami wnętrze.

Lalka jako bohaterka wierszy i opowiadań dla dzieci pojawia się w literaturze czwartej niemal od początków jej istnienia. Wpisuje się ona $\mathrm{w}$,jeden z podstawowych chwytów fabularnych literatury dla dzieci młodszych" (Papuzińska, 
2002, s. 286), jak pisze Joanna Papuzińska o ożywionych zabawkach. Pozwalają one dziecięcemu odbiorcy na poczucie się mądrzejszym i bardziej doświadczonym mentorem, a zarazem wychowawcą, wypróbowanie roli dorosłego, rodzica. Anna Czabanowska-Wróbel zauważa:

W wierszach dla dzieci dziewczynka lub dziewczynki bawiące się lalkami odtwarzają zachowania dorosłych kobiet. Pouczają lalki, śpiewają im i opowiadają, [...] wreszcie - tak jak ich matki - ostrzegają swoje wychowanki przed nadmiernym strojeniem się i dbaniem o urodę [...].

Dziewczynki w zabawie narzekają na swoje „dzieci i na kłopoty, których im przysparzają [...]".

Czabanowska-Wróbel, 2013, s. 158

Badaczka podsumowuje $\mathrm{w}$ ten sposób wiersze $\mathrm{z}$ lalkowymi bohaterkami Marii Konopnickiej. Podobnie dzieje się w utworach Ewy Szelburg-Zarembiny. Wierszyki Reni rozpoczyna czterowiersz:

Mamusia ma Renię.

Renia ma laleczkę.

Każdy na tym świecie

ma swoją córeczkę.

Szelburg-Zarembina

Nie inaczej w Lalkach Dorotki Beręsewicza. Kiedy tata narzeka na "figle i psoty" dwójki dzieci, Dorotka ma gotową odpowiedź:

[...] masz dzieci tylko dwoje.

Znoś to to, tato, ze spokojem.

Bo co powiesz o mym losie?

Ja mam chyba ponad osiem rozbrykanych córek-lalek

i zajęta jestem stale

szyciem, praniem, gotowaniem, prasowaniem i sprzątaniem, usuwaniem szkód po lalach, bajeczkami o krasnalach, poprawianiem zachowania, znajdywaniem rozwiązania, odganianiem strasznych stworów, rozwiewaniem złych humorów, całowaniem drobnych stłuczeń, uciszaniem smętnych buczeń, zdrapywaniem z lalek błota i ty mówisz o kłopotach? 
Ta wyliczanka - jeden z częstych chwytów w wierszowanych utworach Beręsewicza (charakterystyczny, oczywiście, w ogóle dla poezji dziecięcej) - jest katalogiem rodzicielskich zadań i zachowań, nie tylko czasochłonnych, polegających na zapewnieniu dziecku warunków bytowych (szycie, pranie, gotowanie), ale też tych drobnych, wyraźnie jednak najważniejszych z punktu widzenia najmłodszych (pocieszanie, opowiadanie bajek, całowanie). Na plan pierwszy wysuwają się w tej wyliczance właśnie emocjonalne potrzeby dziecka.

Prawdziwe emocje - silne i skrajne - to z pewnością wartość debiutanckiego tomiku Beręsewicza. Czułość, zniecierpliwienie, radość, filozoficzna zaduma (wiersz Czy dzisiaj jest jutro?), opiekuńcza miłość zdolna do walki o ukochane lalkowe córki (Ciężkie życie), ale też niepohamowana złość, w której Dorotka rzuca zabawkami (Kaskaderka), i dojmująca zazdrość o chomika, a może też o umiejętności perswazyjne Weroniki:

\author{
Czemu takiej Weronice \\ ulegają wciąż rodzice, \\ a ci moi od początku \\ nie chcą słyszeć o zwierzątku, \\ chociaż proszę, błagam, szlocham? \\ Chyba nikt mnie już nie kocha! \\ Pocieszanki, LD, s. 22
}

Ostatnie zdanie usłyszał choć raz pewnie każdy rodzic, a większość (jeśli nie wszystkie) dzieci doskonale zna takie stany ducha. To jest też od początku twórczości walor tekstów Pawła Beręsewicza: psychologiczna prawda dziecięcego doświadczenia. Czasem doświadczenie to opisywane jest z wyraźnym dystansem rozbawionego dorosłego, stąd specyficzny humor autora serii o rodzinie Ciumków. I być może m.in. dzięki temu jego teksty czytają z równą satysfakcją dzieci i rodzice.

Lalki Dorotki są tomikiem, który wyróżnia się spośród współczesnych książek $\mathrm{z}$ wierszami dla dzieci również ze względu na zróżnicowanie formalne i kształt artystyczny. Każdy z dziesięciu utworów jest inny pod względem budowy, rytmu, układu i rodzaju stosowanych rymów (pojawiają się też rymy wewnętrzne). Są tu wiersze stychiczne i stroficzne o różnym rozmiarze zwrotek. Rokendrolka naśladuje rytm tańca z powtarzającym się refrenem: „Rock, / rock, / rock przez cały rok" (wiersz zaczyna się od charakterystycznego liczenia kroków przy nauce tańca: „raz, / dwa, / raz, dwa, trzy”; refren odtwarza tak wybijany rytm). Większość wierszy to dialogi, świetnie oddające zarówno sposób mówienia, jak i problemy, a także zabawy kilkulatka. Otwierająca tomik Gocha to ciąg cierpliwie udzielanych przez dziewczynkę odpowiedzi na dwunastokrotnie (!) powtórzone pytanie tytułowej bohaterki „A dlaczego?”. Czy dzisiaj jest jutro? - to filozoficzna rozmowa lalki i misia na temat dziwnej natury czasu i sposobów nazy- 
wania jego upływu. Ciężkie życie zaczyna westchnienie taty skierowane do żony, a podsłuchane przez Dorotkę, która podejmuje rozmowę-dyskusję (polemikę). Wywiad, jak sama nazwa wskazuje, składa się z pytań „redaktora Pluszaka” i odpowiedzi „wielkiej aktorki, laleczki Lilly”. Zamykające tomik Pocieszanki to wzruszająca wymiana zwierzeń między Dorotką i jej zabawką. Najpierw laleczka opowiada dziewczynce o swoich sercowych kłopotach, a później to dziecko odkrywa swoje tajemnice i powody smutku. Dla obu najlepszym lekarstwem okazuje się przytulanie, sprowadzające niezawodnie słodki sen.

Każdy kolejny utwór buduje atmosferę bezpieczeństwa, wzajemnej troski, miłości, chęci zrozumienia. Mama i tata pozornie występują tylko w tle, ale w istocie to ich można uznać za partnerów zabaw i dialogów małej córeczki. Już w pierwszym wierszu Dorotka mówi do lalki Gochy, że dostała ją w prezencie od mamy, która lubi, jak się jej dziecko cieszy, bo je kocha. W drugim utworze podmiotem jest lalka Róża, marząca o karierze modelki. W spełnieniu marzenia mają jej pomóc rady Dorotki, ale ostateczną instancją, do której można się udać po pomoc, jest tata. Charakter problemów Róży raczej nie należy do męskich kompetencji, co powoduje efekt humorystyczny (ale też tym bardziej uwydatnia mocną wiarę dziecka w możliwości, umiejętności i wiedzę ojca):

Lecz nim mnie to wszystko spotka,

Wytłumaczy mi Dorotka,

Jaką wkładać mam sukienkę,

Jak podawać $\mathrm{z}$ gracją rękę,

Jak zaplatać mam warkoczyk,

Jak zalotnie mrużyć oczy.

Oj, już ona zna się na tym,

A jak nie - to spyta taty.

Warstwa leksykalna, stanowiąca często o sile późniejszych prozatorskich książek Beręsewicza, już tu budzi uznanie. Autor stosuje słownictwo charakterystyczne dla kilkulatka, co nie znaczy, że język wierszy jest ubogi. Małe dzieci doskonale (czasem lepiej niż dorośli) znają specjalistyczne terminy, związane z dziedziną, którą się fascynują. W przypadku Dorotki i jej lalek jest to moda (pojawiają się: fani, wybieg, autograf, kariera), taniec (rock and roll, samba, twist). W języku bohaterek nie brakuje też frazeologizmów i wyrażeń potocznych: „zacięła ci się płyta” (s. 3), „,raz dwa do łóżek”, „przepadać za kimś”, „strach nas blady przeszył aż do kości” (s. 13), „wziąć się za kogoś, dobrze wam zrobi...”, ,już po mnie”, „idą ciężkie czasy...”. Oprócz wyliczeń najczęściej stosowanym środkiem artystycznym są onomatopeje i wykrzykniki. Wypełniony jest nimi zwłaszcza wiersz Kaskaderka o złoszczącej się Dorotce.

Świat Lalek Dorotki to oczywiście świat dziecięcej zabawy, „przymierzania” różnych ról podpatrzonych u dorosłych. W zabawie Dorotki wiele jest odniesień 
do bajek i baśni, zapewne czytanych przez rodziców, a także do bohaterów popkultury, takich jak James Bond. Cieniutki tomik Beręsewicza dzięki intertekstualnym odniesieniom może służyć za przewodnik po koniecznych lekturach dla kilkulatków. Mowa jest o Królowej Śniegu (Modelka), o Śpiącej Królewnie, Calineczce, Syrence, Czerwonym Kapturku i Kopciuszku, o Puchatku (Wywiad). Widać, jak te wszystkie baśniowe opowieści oddziałują na wyobraźnię dziewczynki, wpływając na jej własne scenariusze zabaw (Bajka dla lalek).

Dziecięca zabawa to ćwiczenia wyobraźni, badanie obszarów, na które nie da się wkroczyć, a które eksploruje się tylko poprzez stwarzanie, za pomocą performatywnego gestu, światów równoległych wobec rzeczywistego. Za pośrednictwem lalek dzieci mogą poznawać konsekwencje swoich decyzji, uczestniczyć w kreowanych przez siebie wydarzeniach, ale też jak w teatrze - zyskiwać dystans do odgrywanych scen.

Czabanowska-Wróbel, 2013, s. 163

Lalki Dorotki stanowią tego doskonałą egzemplifikację.

Drugą książkę z wierszami Paweł Beręsewicz wydał, tym razem w wydawnictwie Literatura, pięć lat po pierwszej (na trzecią potrzebował kolejnych dziewięciu lat). Czy pisarzom burczy w brzuchu? z 2009 roku to wierszowana relacja ze spotkań autorskich $\mathrm{z}$ dziećmi. Znów powraca temat ważny dla literatury dziecięcej, zwłaszcza wierszowanej. Jak pisze Edward Balcerzan,

Poezja dla dzieci nie ukrywa przed odbiorcą swej literackości. Jednym z ważnych bohaterów tej twórczości - obok dziecka, krasnoludka, mysikrólika, słonia czy maszyny - jest właśnie „poeta”, „ten, co pisze wiersze”, „autor”...

Balcerzan, 1978, s. 57

Choć taki bohater znany jest $\mathrm{z}$ tomików dziecięcych już od Stanisława Jachowicza ${ }^{1}$, to poświęcona mu cała książka stanowi raczej wyjątek. Wątki autotematyczne oraz metafikcyjne są obecne na coraz większą skalę w literaturze, także dziecięcej, w tym w poezji końca XX i początku XXI wieku (zob. Zabawa 2013, s. 163-181). Poetyckie autoportrety jednak to zazwyczaj pojedyncze wiersze (np. L.J. Kern, Ja o mnie; W. Chotomska, Autoportret). W tym przypadku Beręsewicz prezentuje się jako pisarz w dwudziestu jeden utworach.

Tym razem zderzenie z lirycznymi, ale niepozbawionymi humoru ilustracjami Iwony Całej, podkreśla charakter wierszy. Stanowią one odpowiedzi na postawione w tytułach pytania, które w większości zaczynają się od „czy” (czternaście na dwadzieścia jeden), a więc wymagają odpowiedzi „tak” lub „nie”. Tym-

${ }^{1}$ Wybór takich wierszy zamieszcza w swojej antologii poezji dla dzieci Ryszard Waksmund w pierwszym rozdziale pt. Wiersze dedykacyjne, programowe i autotematyczne (Waksmund, 1999, s. $43-51)$. 
czasem autor za każdym razem rozbudowuje swoją wypowiedź o anegdotę, przewrotne dopowiedzenie, grę słowną. Wybrane dziecięce pytania rzeczywiście zaskakują, jak obiecuje pisarz we wstępie. Dotyczą życia osobistego (o bogactwo, posiadanie zwierzątka, dzieci, żonę i szkołę), jak również zawodowego (o pomysły do książek, konieczne zmiany, narzędzie pisarskie, ulubione książki i początki kariery). W tych kategoriach nie bardzo mieści się tylko pytanie, które stało się tytułem całego tomiku - najbardziej niezwykłe, chciałoby się powiedzieć fizjologiczne. Kryje się za nim jednak bardzo interesująca rzeczywistość, a mianowicie częste utożsamianie osób uprawiających zawody artystyczne z bytami wyższymi, innego porządku, bardziej duchowymi - takimi, które nie muszą zaspokajać żadnych niższych potrzeb związanych z bytem cielesnym, podległym prawom biologii.

Obrazowi poety z wiersza Gałczyńskiego - „tajemniczego człowieka, / który miał złote książki i zielone pióro", Beręsewicz przeciwstawia zwykłego ojca rodziny, piszącego na komputerze, denerwującego się "niegrzecznością” potomstwa i takiego, któremu... „czasem burczy” w brzuchu. Deziluzja jednak nie jest całkowita:

Jest pisarzy jak gwiazdek na niebie i nie znam wszystkich ich tajemnic twórczych.

Ja tylko mogę powiedzieć za siebie:

mnie czasem burczy.

Cp, s. 9

Nadawca w analizowanej książce jawi się tak, jak w charakterystyce sporządzonej przez Bogusława Żurakowskiego:

[...] w sposób jak najbardziej wyraźny pragnie zbliżyć się do dziecka. Sięga więc po formy wytworzone przez dzieci. Próbuje dotrzeć do tego, co w dziecięctwie najbardziej charakterystyczne: do ducha fantazji, ducha zabawy oraz prostoty bycia i myślenia.

Żurakowski, 1999, s. 18

W tym tomiku dorosły poeta wręcz czyni dziecko współautorem, przytaczając zadawane mu przez najmłodszych pytania i starając się dostosować odpowiedzi do dziecięcego sposobu postrzegania świata. Stale przy tym balansuje między perspektywą dorosłego i dziecka, co stanowi zresztą charakterystyczną cechę całej jego twórczości.

Interesujące ramy tomiku zostały utworzone przez wiersze pierwszy i ostatni. Pojawiają się w nich bowiem wzmianki o książkach innych autorów. W pierwszym przypadku chodzi o angielski bestseller o nastoletnim czarodzieju. Autor przedstawia się jako ten, który potencjalnie mógł wpaść na taki sam pomysł. Niestety, „ktoś” zrealizował go wcześniej, pozbawiając polskiego pisarza szansy 
na wielki majątek (Czy jest pan bogaty?). W ostatnim utworze tomiku natomiast w sześciu zwrotkach opisana została szczególna lektura z dzieciństwa Pawła Beręsewicza (Jaka była pana ulubiona książka, kiedy był pan mały?):

$[\ldots]$
czytałem o człowieku,
który miał ogromną siłę.

Siłę tę nie w mięśniach chował, lecz w mózgowych zwojach krętych.

Kiedy w ruch szła jego głowa, drżały łotry, zbiry, męty.

Ten bohater kiedy chciał, to Umiał wygrać w każdej gierce, Miał najbrzydsze w świecie auto I najlepsze w świecie serce.

Chodzi oczywiście o serię książek o Panu Samochodziku Zbigniewa Nienackiego. Ciekawe, że w wierszach umieszczonych w tak kluczowych miejscach, jak początek i koniec tomiku, autor zdecydował się powołać nie na własne, lecz cudze utwory. Wydaje się, że to jeden $\mathrm{z}$ wielu gestów sygnalizujących dystans pisarza do własnej pracy twórczej. Dziecięcy humor (także czarny, rodem z dziecięcego folkloru, jak w czterowierszu Czy pan lubi dzieci?) i autoironia to znaki rozpoznawcze nie tylko tego autotematycznego tomiku.

Proces twórczy, według autora, również nie ma w sobie wiele z romantycznej tajemniczości. Zostaje tu porównany do polowania. Pomysły pisarskie „Kicają dziarsko hyc, hyc, hyc!" (Cp, 10), a twórca najwyraźniej łapie je gołymi rękami. Zabawne przesunięcie w udosłownieniu metafory widać na ilustracji, na której pisarz gania za pomysłami z siatką na motyle. Sądzę, że artystce taki sposób polowania mógł się wydać bardziej... poetycki. W tym wierszu pojawia się tytuł książki, tym razem samego Pawła Beręsewicza: Jak zakochałem Kaśkę Kwiatek (wyd. 2005). Czy wymienienie tego tytułu to wyraz szczególnego sentymentu pisarza do jednej z pierwszych opublikowanych książek? Na pytanie wprost, które własne dzieło jest mu najbliższe, autor nie chce udzielić odpowiedzi: „Każdą książkę w sercu noszę / [...] / Wybierajcie sami, proszę” (Cp, s. 36).

Porównanie pisania do łowów sugeruje pewien wysiłek. Podobne powiązanie tworzenia $\mathrm{z}$ aktywnością fizyczną, czy wręcz właśnie z trudem niekoniecznie intelektualnym, występuje też $\mathrm{w}$ wierszu-odpowiedzi na pytanie: Czy trudno jest być pisarzem?. Po intensywnym bieganiu

Przez chwilę na podłodze

bez życia prawie leżę, 
a potem, dysząc srodze, spisuję na komputerze me myśli, póki świeże.

Cp, s. 25

Puenta jest w tej sytuacji zrozumiała:

Oj, trudno być pisarzem!

Oj, bolą po tym nogi!

Cp, s. 25

Wątek sportowy (a trzeba dodać, że w analizowanym właśnie tomiku ważną rolę odgrywa również chłopięce marzenie autora o grze w piłkę nożną) łączy drugi tomik wierszy Beręsewicza z trzecim i jak na razie ostatnim, wydanym w 2018 roku przez wydawnictwo Literatura, z ilustracjami mistrza Bohdana Butenki. Nasuwa się spostrzeżenie, że z tomiku na tomik szata graficzna książek z wierszami autora Wszystkich lajków Marczuka była coraz ciekawsza, aż do perfekcji. Rosła też liczba zamieszczonych utworów - od dziesięciu przez dwadzieścia jeden po aż czterdzieści dziewięć!

Złota jedenastka. Wiersze dla kibica i jego rodzica, bo tak został zatytułowany ostatni tomik, prezentuje czterdzieści dziewięć dyscyplin sportowych, być może przez skojarzenie $\mathrm{z}$ dawnym Toto-Lotkiem (?) ${ }^{2}$. Charakter utworów zapowiada już pierwszy z nich, nawiązujący do tytułu całej książki - Piłka nożna: fantastyczne pomysły pomieszane $\mathrm{z}$ realiami, niejednoznaczność (podkreślana ilustracjami Butenki), zwroty do czytelnika i ujawnianie się wrażliwego narratora („Łzę otrę, nie wstydząc się wcale”), fachowe słownictwo sportowe przemieszane $\mathrm{z}$ kolokwializmami (podobnie zresztą jak u zawodowych komentatorów), wreszcie zręcznie, a czasem zaskakująco zrymowany wiersz. Długa forma szesnastozwrotkowego „poematu” futbolowego sąsiaduje z krótszym wierszem stychicznym zakończonym dobitną puentą, którą autor wyodrębnił dodatkowo, stosując krótki czterozgłoskowy wers po dłuższym fragmencie pisanym dziesięciozgłoskowcem (Skoki narciarskie). W utworze Himalaizm rymy piętrzą się jak kolejne stopnie górskiego wtajemniczenia (zaczynając od zwyczajnych parzystych przez pięciokrotne i sześciokrotne [!], do tego wewnętrzne):

Co jest sprawą oczywistą, wcześniej byłem alpinistą,

2 Takie było moje pierwsze skojarzenie, które jednak okazało się nadinterpretacją. W wywiadzie udzielonym Barbarze Gawryluk Autor przyznał, że nie jest pewien, ile utworów zamieścił w tomiku. Myślał o setce, ale zdał sobie sprawę, że to będzie za dużo i poprzestał na... pięćdziesiątce. Wywiad w audycji B. Gawryluk, Alfabet, Radio Kraków 1 marca 2020 [nagranie z czerwca 2019]. Fragmenty części artykułu o Złotej jedenastce zostały opublikowane w „Nowych Książkach” 2019, nr 11 pt. 49 dyscyplin sportowych Pawła Beręsewicza. 
taternikiem, sudecistą,

pieninnikiem, bieszczadystą

i górzystą świętokrzystą.

Przytoczony fragment ujawnia jeszcze jeden charakterystyczny rys sportowych wierszy Beręsewicza, a mianowicie skłonność do zabawy słowami: tworzenia neologizmów, wykorzystywania homonimów i zabawnych skojarzeń językowych. Pozostając w klimacie Złotej jedenastki..., można uznać, że jest ona przykładem słownej żonglerki i językowej akrobatyki. Nie mogło zatem zabraknąć w niej, coraz popularniejszych wśród polskich pisarzy i poetów, popisów sprawności pióra - limeryków, np. Rzut dyskiem, Rugby, Rzut oszczepem, Łucznictwo, Snooker. Tytuły wykazują również wielkie zróżnicowanie „opisywanych” dyscyplin sportowych: od bardzo popularnych przez niszowe do znanych raczej tylko nielicznym, takich jak wyścig z serem czy strącanie z kłody (logrolling). Przy okazji autor wprowadza elementy języków obcych, które jeszcze bardziej komplikują językowy obraz całości. Na przykład w wierszu Szermierka padają komendy: „En garde!”, „Prêts!”, „Allez!” (i to wszystkie w pozycji rymowej; autor rymuje $\mathrm{z}$ nimi polskie słowa). W warstwie leksykalnej rzucają się też w oczy liczne nazwy własne: imiona, nazwiska, toponimy. Ta właściwość wierszy Beręsewicza zasługiwałaby na osobny szkic. Wymienione słowa pełnią różne funkcje. Mogą wywoływać efekt humorystyczny, jak wyliczenie imion graczy tytułowej „złotej jedenastki” oraz wspólne nazwisko piłkarzy, które brzmi Kot i jest podstawą do zabawnego udosłownienia ilustracji. Mają wartość poznawczą, jak w drugim wierszu tomu pt. Maraton, gdzie padają historyczne imiona - Dariusz, Miltiades, Filippides. Dziecięcy odbiorca zetknie się w książce z wieloma nazwami narodowości (m.in. Grek, Pers, Niemiec, Francuz) i państw (m.in. San Marino, Gwatemala, Białoruś, Honduras - to nazwy wypisane tylko z jednego wiersza - Akrobatyka).

Swoją różnorodność i wielobarwność tomik zawdzięcza zarówno wielości form literackich, zróżnicowaniu języka oraz mówiącego podmiotu, jak i projektowi graficznemu: sposobom tworzenia ilustracji, rozmieszczenia tekstu i rysunku, nietypowemu użyciu czcionki (Biatlon). Bohdan Butenko — „legenda polskiej ilustracji” (jak czytamy na czwartej stronie okładki) — jest czasem niezwykle oszczędny w komentowaniu wierszy, umieszczając na przykład na całej rozkładówce tylko stopę w charakterystycznym obuwiu, ze skrajem starożytnej szaty (Maraton). Jak się okazuje, na kolejnej stronie ten detal ma swoją część dalszą (to nie jedyny przypadek, kiedy rysunek „nie mieści się” na rozkładówce i „przechodzi” na następną stronę). Zdarza się jednak, że artysta tworzy własną całostronicową opowieść (Żeglarstwo, Bieg na 100 m, Pływanie), która stanowi niezależny komiksowy kadr, luźno powiązany z wierszem. Humor, łączący twórczość obu panów B. (Beręsewicz, Butenko), sprawia, że powstała niezwykle spójna całość. 
Podtytuł książki Beręsewicza i Butenki brzmi: wiersze dla kibica i jego rodzica. Rzeczywiście, to lektura familijna (podobnie zresztą jak właściwie wszystkie utwory tego pisarza), inspirująca do rozmów, poszukiwań internetowych (warto obejrzeć filmik z zawodów w wyścigu z serem Gloucester!), własnych prób rymotwórczych i plastycznych, a może nawet do wspólnej aktywności fizycznej...

Podsumowując, znany przede wszystkim z utworów prozatorskich Paweł Beręsewicz $w$ trzech tomikach wierszy ukazuje jeszcze inną stronę swojego talentu: łatwość rymowania, wyczucie melodii i rytmu wiersza, umiejętność zawarcia $\mathrm{w}$ łatwo wpadającej $\mathrm{w}$ ucho formie bardzo różnych treści - humorystycznych, wesołych, ale i całkiem poważnych. Choć rzadko, jednak od czasu do czasu zdradza również, że nieobcy jest mu liryzm, na ogół co prawda (jakby autor przestraszył się „niemęskiego” sentymentalizmu) od razu przełamywany nagłym prozaizmem czy dowcipem, jak w wierszu: Jaki jest pana ulubiony kolor?:

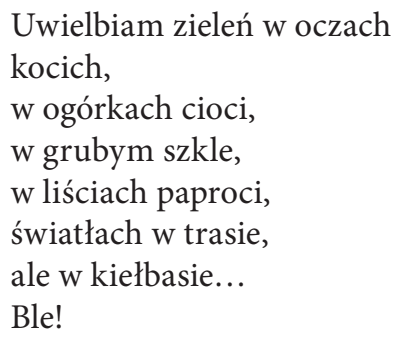

Analizowane książki z wierszami bardzo dobrze wpisują się w całość twórczości Beręsewicza, ukazując jego fascynacje dziecięcym światem zabaw i wyobraźni, sportem (co poświadcza też np. powieść Więcej niż klub, 2016), a może przede wszystkim - słowami i niezwykłymi możliwościami języka (udowadnianymi też we wszystkich książkach prozatorskich).

\section{Literatura}

Balcerzan E., 1978, Odbiorca w poezji dla dzieci, w: Białek J.Z., Guśpiel M, red., Literatura dla dzieci i młodzieży. Teoria i krytyka. Wybór tekstów, Kraków.

Beręsewicz P., 2011, Lalki Dorotki, Ostrowska M., ilustr., Kraków (LD).

Beręsewicz P., 2009, Czy pisarzom burczy w brzuchu?, Cała I., ilustr., Łódź (Cp).

Beręsewicz P., 2018, Złota jedenastka. Wiersze dla kibica i jego rodzica, Butenko B., ilustr. i oprac. graf., Łódź 2018 (Zj).

Czabanowska-Wróbel A., 2013, Lalki Konopnickiej, w: Tejże, Sprzeczne żywioły. Młoda Polska i okolice, Kraków, s. 157-168.

Papuzińska J., 2002, [hasło] ożywione zabawki, w: Tylicka B., Leszczyński G., Słownik literatury dziecięcej i młodzieżowej, Wrocław, s. 286-287. 
Waksmund R., oprac., 1999, Poezja dla dzieci. Antologia form i tematów, Wrocław 1999. Zabawa K., 2013, Rozpoczęta opowieść. Polska literatura dziecięca po 1989 roku wobec kultury współczesnej, Kraków.

Żurakowski B., 1999, Literatura - wartość - dziecko, Kraków.

Krystyna Zabawa - dr habilitowany, prof. AIK, kierownik Katedry Nauk o Literaturze Instytutu Neofilologii Wydziału Pedagogicznego Akademii Ignatianum w Krakowie. Autorka m.in. monografii Rozpoczęta opowieść. Polska literatura dziecięca po 1989 roku (2013) oraz Literatura dziecięca w kontekstach edukacyjnych (2017). Członkini Polskiej Sekcji International Board on Books for Young People (IBBY), Rady Konsultacyjnej Ośrodka Badań Literatury Dziecięcej i Młodzieżowej Wydziału Polonistyki Uniwersytetu Jagiellońskiego oraz Rady Programowej Centrum Literatury Dziecięcej Miejskiej Biblioteki Publiczej w Oświęcimiu. Stała współpracowniczka „Nowych Książek”, regularnie publikująca recenzje, zwłaszcza książek dla dzieci. Zajmuje się naukowo literaturą dziecięcą oraz literaturą przełomu XIX i XX wieku (przede wszystkim poezją).

e-mail: krystyna.zabawa@ignatianum.edu.pl 